előtte tisztelgő volt diákjai - ma már meglett emberek, akik között van újságíró, orvos, kereskedelmi tanácsos, filmrendező, színész, zenész, tanár, könyvkiadó - mindnyájan az ő titkát próbálják megfejteni, szavakba önteni: miért is szerették annyira, mivel is írta be a lelkükbe magát egész életükre. Vajon mit tudhatott ez a magas, sportzakós, hamiskás mosolyú, szép, mastroiannis fiatalember, hogy ilyen megható férfiszeretettel idézték fel alakját? Mivel zabolázta meg, s tette az irodalom, a kultúra szerelmesévé a saját bevallása szerint is lógós ,újpesti csibész” diákját, vette rá őt és a többieket is, hogy önképzőkörben szerepeljenek, antológiát szerkesszenek, színjátszó szakkört hozzanak létre, hogy az alsópéli (KISZ) táborban a kukoricacímerezés, borsónyűvés után az ebédlőben Calderón-színdarabot adjanak elő? Pedig szigorú elvárásai voltak: memoriterfüzetet vezettetett, ahova bemásoltatta a megtanulandó verseket, nyárra (hosszú) kötelező olvasmánylistával látta el őket, és olvasónaplót is kellett írniuk. Számos magyarázattal szolgáltak a titkára: „törődött velünk, segített és bíztatott” (189); „El tudta velünk hitetni, hogy közösen valami nagyon fontos dolgon munkálkodunk” (182); „elérte, hogy mindig akarjunk valamit”; „Egyszerre nevelt bennünket igényessé, önállóvá és felelőssé” (i. h.). A végső válasz azonban valószínüleg csak ennyi: ő volt ,,az Éder tanár úr”.

Így igaz, nem volt könnyü az ő iskolájában tanulónak lenni! Jómagam, két kollégámmal, Hegedűs Ritával és a tragikusan korán elhunyt Kálmán Péterrel abban a szerencsében részesültünk, hogy a 80-as években, a magyar mint idegen nyelv szak létrehozásának úttörö éveiben mellette tanulhattunk, csiszolódhattunk, bontogathattuk szárnyainkat tanársegédként. Pályám során számtalanszor voltam hálás az akkoriban (nemegyszer) kelletlenül teljesített újra- és újrafogalmazásokért, javításokért, utánanézésekért. Már tudom, életre szóló, belülről kényszerítő örökséget kaptam tőle, amit - most, életem legnehezebb írásával küszködve is - hálásan köszönök.

Éder Zoltán tanár úr elnyerte a legfőbb jutalmat a sorstól, a Teremtőtől: noha fájdalmasan korán visszavonult, felesége-társa óvó, megtartó szeretetében szép, tartalmas éveket élhetett meg lemezei, kedves könyvei között. És megadatott neki a legnagyobb égi kegy: csendben, méltósággal mehetett el. Tisztelt Tanár Úr, nyugodjék békében!

SZILI KATALIN

Eperjesi Egyetem

\title{
Búcsú Balogh Lajostól
}

(1933-2020)*

Szomorú szívvel veszek búcsút Balogh Lajostól, az embertől, a tudományos kutatótól, a magyar nyelvjárások kitünő ismerőjétől, a magyar dialektológia elismert müvelöjétől. Távoztával jó barátot, pályatársat és közeli kollégát veszítettünk el. Búcsúzom tőle a Magyar Nyelvtudományi Társaságnak és az Eötvös Loránd Tudományegyetem Bölcsészettudományi Kara magyarnyelvészeinek a nevében.

*Elhangzott temetésén 2020. március 28-án Bükön, a Petőfi Sándor utcai temetőben.

DOI: 10.18349/MagyarNyelv.2020.2.241 
Balogh Lajos Bükön született 1933-ban, s lélekben mindig is büki maradt. S ezt nemcsak a Kossuth utcai szülői ház eredetiben való megőrzése és gondozása mutatja. Büki tájszótára is a szülöfaluhoz, az itt töltött gyermekkorhoz való hüséges kötődésnek a szép bizonysága. Szótárában ezeknek állított maradandó emléket. De nemcsak ez a szótár, hanem a Bük történetéről írott tanulmányai, visszaemlékezései is ebbe a sorba tartoznak (1. például a 20. század középső évtizedeire visszatekintő, Büki emléktöredékek címü remek írását a Vasi Szemlében [Balogh 2015]).

Balogh Lajos régi mankóbüki, azaz alsóbüki nemesi családból származott. Ritkán, de említette, hogy a reformkor ismert alakja, a magyar nyelv elismertetéséért folytatott küzdelemben élen járó Felsőbüki Nagy Pál is büki volt. Balogh Lajos a fővárosi egyetem bölcsészkarán magyar és történelem szakon tanult, a Ménesi úti kollégium tagja volt, szakdolgozatát magyar nyelvészetből s Benkő Lorándhoz írta. 1959-ben szerzett diplomát. Ezt követően egy évig Szombathelyen középiskolában tanított, majd 1960-tól 1996ig, nyugalomba vonulásáig az MTA Nyelvtudományi Intézetének volt munkatársa. Ezzel pedig „,egy magas színvonalú szakmai közösségnek” vált tagjává (ahogy ő maga írta). Itt 1972-től az akkor kibontakozó regionális köznyelvi kutatások témavezetője lett. Az ELTE Bölcsészkarán 1970 és 1980 között óraadó tanár volt. Segítségünkre volt az ELTE magyar szakos hallgatói nyelvjárásgyüjtő útjainak a szervezésében. A magyar nyelvtudomány legnagyobb vállalkozásának, a nagy magyar nyelvjárási atlasznak a munkálataiba kapcsolódott a Nyelvtudományi Intézetbe kerülve, s részt vett (Deme László mellett) az atlasz ellenőrző s hangfelvételeket is készítő gyüjtéseiben (1970-tól 1974-ig), miként az Új magyar tájszótár előkészítő munkálataiban is. Bekapcsolódott az Európai Nyelvatlasz és a Kárpát Nyelvatlasz munkálataiba, s a magyarországi földrajzi nevek gyüjtésébe és közzétételébe. 1976-ban jelent meg Király Lajossal közösen írt munkájuk, Az állathangutánzó igék, hívogatók és terelők somogyi nyelvatlasza. 1990-től négy éven át az Ungvári Állami Egyetem magyar vendégtanáraként dolgozott Ukrajnában. Ő írta a Magyar dialektológia címü nyelvjárástani szintézisbe a magyar nyelvjárásszigetekről szóló fejezetet (BALOGH 2001). Tagja volt az Új magyar nyelvjárási atlasz koncepcióját kidolgozó s munkálatait előkészítő szük szakmai körnek (2007-ben): erre széles körü nyelvjárási ismerete, a regionális szókészletben és az atlaszkészítésben való jártassága tette alkalmassá. Ö volt A magyar nyelvjárások atlasza nagy nemzedéke és a magyar dialektológusok későbbi nemzedékének tagjai közötti egyetlen összekötőkapocs, aki nyelvtudomány-történeti tapasztalataiból sokat megosztott a hozzá közel állókkal. Legismertebb önálló munkáját, a 2004-ben megjelent Büki tájszótárt (BükiTsz.) méltó külsőségek között mutatták be 16 évvel ezelött a büki Müvelődési Központban. A szótár bővített második kiadása 2016-ban jelent meg Bük első írásos említésének 750. jubileumi évében. Nem maradhat említetlen: neki köszönhető, hogy a magyar nyelvészek 14. élőnyelvi konferenciája 2006 őszén Bükön volt. Szívesen emlékezünk a hasznos tudományos előadásokra s a kellemes büki környezetre. Miként arra az élményre is, amit Balogh Lajos muzeális értékü és berendezésű, müemlékké nyilvánított szülőházának megtekintése és az ő kalauzolása jelentett. Munkásságát különböző kitüntetésekkel jutalmazták: a Magyar Nyelvtudományi Társaság a Csüry-emlékéremmel és -díjjal (1977), illetőleg a Pais Dezső-díjjal (2005) tüntette ki. De méltán nyerte el a Bük városért (2010) és a Veszprém megyéért (1983) nevezetü kitüntetést is. V. éves egyetemistaként lett a Magyar Nyelvtudományi Társaság tagja, 1980-tól 2005-ig, tehát negyed századon át e tudományos társaság pénztárosa (1. MNy. 1981: 245 és 2006: 114), több cikluson át 
a Csüry Bálint-díj és -emlékérem odaítélésére javaslatot tevő bizottságnak és évtizeden át a Társaság választmányának a tagja is volt. 80. születésnapja alkalmából a Magyar Nyelvtudományi Társaság nyilvános felolvasó ülésén köszöntötte. Zelliger Erzsébetnek, az ünnepelt munkásságát lelkiismeretes alapossággal bemutató laudációja kitünő összefoglalás Balogh Lajos munkásságáról (ZELLIGER 2014). A mondottakból kivilágolhat, miért pótolhatatlan veszteség - a dialektológusok számának radikális visszaszorulására is gondolva Balogh Lajos elhunyta a magyar nyelvjáráskutatásra nézve.

Mi - évtizedeken át közeli munkatársai, barátai - az embert külön is gyászoljuk. Takarékos beszédü, férfiasan szemérmes, önmutogatás nélkül dolgozó ember, a karrierista ellenpéldája volt. Felejthetetlen marad mindenkor való, kizökkenthetetlen nyugalmáról is. Soha nem láttam felindultnak. Sportos életformája alapján (kajaktúrákon vett részt, szívesen úszott) hosszú életet jósoltak neki ismerősei. 80 évesen melankóliával jegyezte meg a nagyatlaszosokra utalva, hogy „,csak én vagyok már az élők sorában”. S mivel a kor előrehaladtával sajnos egyre inkább egészségi gondokkal kényszerült küszködni, a tudományos tervek megvalósításáról is le kellett mondania. Érzéseit jubiláris évében röviden így summázta: „nem jó 80 évesnek lenni”. S bizony a követő években egyre többet veszített erejéből, munka- és mozgásképességéből, magabírásából - feleségének, illetőleg családjának odaadó gondoskodása ellenére is.

A temetés szomorú perceiben különösen is érezzük hiányát. De tudjuk, hogy emlékezetünkben megmarad. Nem feledhetjük szelídségét, segítőkészségét, derüs nyugalmát, halk szavú bölcsességét. Ahogy nem felejthetik a bükiek sem, hiszen ők neki köszönhetik a már múlttá vált büki kifejezések és a hagyományos paraszti gazdálkodás szavainak a megmentését s mindannyiunk, sőt a jövendő számára való közkinccsé tételét is.

Kedves Lajos! Fájó szívvel búcsúzunk Tőled. Emlékedet megőrizzük. Isten Veled!

\section{Hivatkozott irodalom}

BALOGH LAJOS 2001. A nyelvjárásszigetek. In: KISS JENÖ szerk., Magyar dialektológia. Osiris Kiadó, Budapest. 316-324.

Balogh Lajos 2015. Büki emléktöredékek. Vasi Szemle 69: 521-534.

BükiTsz. = BALOGH LAJOS, Büki tájszótár . Vasi Szemle Szerkesztősége, Szombathely, 2004.

ZELLIGER ERZSÉBET 2014. Balogh Lajos 80 éves. Magyar Nyelv 110: 252-254.

KISS JENÖ

ELTE Eötvös Loránd Tudományegyetem

\section{Lizanec Péter 90 éves}

Komoly feladat ünnepeltünk pályájának bemutatására vállalkozni. Kulcsszavakként így jellemezném: hűség az alma materhez, megfontolt tudományszervezés, folyamatos kutatás, lelkiismeretes, kitartó munka. Élete 1948-tól napjainkig elválaszthatatlan az ungvári egyetemtől. 